\title{
Analysis of the impact of the allocation of European funds on rural development in Romania
}

\author{
Alina Mariana (Popa) Podaru ${ }^{1}$, and Adrian Turek Rahoveanu, ${ }^{1, *}$ \\ ${ }^{1}$ University of Agronomic Sciences and Veterinary Medicine of Bucharest, 59 Marasti Blvd, \\ Bucharest, Romania
}

\begin{abstract}
Rural development within the European Union has been a continuous evolution of rural space through which it has responded to the needs and challenges of the European Community. Thus, the European Union has created and implemented the Common Agricultural Policy, and rural development is its second pillar. In the case of Romania, agriculture and rural development is a priority sector in terms of economic and social growth, due to the large area occupied by rural areas, but also due to the large area of agricultural land that is found on the territory of Romania. This article is intended to be an objective analysis of the impact that European funds have had on the development of the Romanian rural area regarding the allocation of these funds. At the same time, the degree of absorption of the National Rural Development Program (NRDP) was analysed.
\end{abstract}

Keywords: European funds, rural development, economic growth

JEL Classification: $Q 01 ; Q 15 ; Q 18$;

\section{Introduction}

The territory of Romania illustrates the harmony of the geographical structure and the agrarian potential - starting with the relief forms; hydrographic network, soil, vegetation, land use, land improvement arrangements and concluding with roads, network of localities and economic activities, which reflects its natural-economic values integrated in a continuous process of development, capitalization, restructuring, arrangement and harmonious organization [6].

Romania represents $6 \%$ of the total area of the European Union and $4 \%$ of its population. Investments and competitiveness in Romania are elements that need to be improved, in order to achieve an acceleration of economic growth and ensure a convergence of revenues with those in the $\mathrm{EU}[3,13]$.

Romania's agriculture is inhomogeneous in terms of exploitation structures, and their dual character is accentuated compared to the vast majority of European Union member states. Although some progress has been made, an excessively large number of nonperforming individual, small and very small non-performing holdings is maintained, as well

\footnotetext{
*Corresponding author: turek.adrian@managusamv.ro
} 
as a small number of large and very large units whose activity has not been restructured to become compatible with market requirements. unique $[4,7,15]$.

According to Eurostat statistics, there are 10,467 thousand farms in the EU-28. These farms use an area of 173.3 million ha, the average area of a farm being 16.5 ha. In Romania there are 3,422 thousand farms, which use 12.5 million ha, with an average area per farm of 3.65 ha.

Table 1. Total number of agricultural holdings, utilized agricultural area and average farm size at EU-28 level

\begin{tabular}{|c|c|c|c|}
\hline Country & $\begin{array}{c}\text { Total number of } \\
\text { agricultural holdings }\end{array}$ & $\begin{array}{c}\text { Agricultural area used } \\
\text { (ha) }\end{array}$ & $\begin{array}{c}\text { Average size of } \\
\text { holdings (ha) }\end{array}$ \\
\hline Belgium & 36,890 & $1,354,250$ & 36.71 \\
\hline Bulgaria & 202,720 & $4,468,500$ & 22.04 \\
\hline Czech Republic & 26,530 & $3,455,410$ & 130.25 \\
\hline Denmark & 35,050 & $2,614,600$ & 74.60 \\
\hline Germany & 276,120 & $16,715,320$ & 60.54 \\
\hline Estonia & 16,700 & 995,100 & 59.59 \\
\hline Ireland & 137,560 & $4,883,650$ & 35.50 \\
\hline Greece & 684,950 & $4,553,830$ & 6.65 \\
\hline Spain & 945,020 & $23,229,750$ & 24.58 \\
\hline France & 456,520 & $27,814,160$ & 60.93 \\
\hline Croatia & 134,460 & $1,562,980$ & 11.62 \\
\hline Italy & $1,145,710$ & $12,598,160$ & 11.00 \\
\hline Cyprus & 34,940 & 111,930 & 3.20 \\
\hline Latvia & 69,930 & $1,930,880$ & 27.61 \\
\hline Lithuania & 150,320 & $2,924,600$ & 19.46 \\
\hline Luxembourg & 1,970 & 130,650 & 66.32 \\
\hline Hungary & 430,000 & $4,670,560$ & 10.86 \\
\hline Malta & 9,210 & 11,120 & 1.21 \\
\hline Netherlands & 55,680 & $1,796,260$ & 32.26 \\
\hline Austria & 132,500 & $2,669,750$ & 20.15 \\
\hline Poland & $1,410,700$ & $14,405,650$ & 10.21 \\
\hline Portugal & 258,980 & $3,641,690$ & 14.06 \\
\hline Romania & $3,422,030$ & $12,502,540$ & 3.65 \\
\hline Slovenia & 69,900 & 488,400 & 6.99 \\
\hline Slovakia & 25,660 & $1,889,820$ & 73.65 \\
\hline Finland & 49,710 & $2,233,080$ & 44.92 \\
\hline Sweden & 62,940 & $3,012,640$ & 47.87 \\
\hline United Kingdom & 185,060 & $16,673,270$ & 90.10 \\
\hline EU-28 & $10,467,760$ & $173,338,550$ & 16.56 \\
\hline
\end{tabular}

Source: Eurostat (online data code: ef_m_farmleg)

In Romania, the share of farms between $0-2$ ha is $70.2 \%$ of the total number of farms, the size of the phenomenon of excessive fragmentation of Romanian agricultural holdings, with negative effects on their economic and development performance. All these extremely modest farms in terms of physical and economic size, produce mainly for their own needs, do not invest and do not generate consumption on the market [11].

This process of fragmentation in small plots leads in many cases to the impossibility of applying modern agricultural agrotechnology technologies that lead, scientifically, to the 
obtaining on cultivated lands of stable productions both in terms of quantity and qualitative. [12].

Non-performance of agricultural production is generated, first of all, by the much too much dependence on annual weather conditions, because irrigation systems are largely degraded and dysfunctional, but also due to the use of outdated agricultural technologies, with low input consumption. those that support performance (quality seed, fertilizers, crop protection substances) and with outdated technical equipment in terms of energy consumption and productivity [8].

At the same time, in Romania, there is a lack of a sector of medium, family and associative farms, which characterizes the "European agricultural model" that was formed for a long time under the impact of the Common Agricultural Policy [2, 14].

After Romania's accession to the European Union, this sector of medium-sized farms benefited from support measures for their modernization, for the acquisition of new equipment and technologies, by facilitating access to European structural funds $[1,5]$.

The European Agricultural Fund for Rural Development (EAFRD) is the financial instrument through which, in the European Union, it ensures the implementation of measures on sustainable rural development, in complementarity with the market and income support policy applied under the Common Agricultural Policy. The EAFRD shall finance Member States through rural development programs aimed at achieving the Union's rural development priorities $[9,10]$.

\section{Methods}

This paper consists of an office research, using the analysis of statistical reports and official documents as a methodological background. In this way, the main data sources for analysis are: Agency for Financing Rural Investments, Interim Reports of the National Rural Development Program; Ministry of Agriculture and Rural Development - General Directorate of Rural Development.

\section{Results and Discussions}

Romania's accession to the European Union had an important impact on the entire national economic activity and, in particular, on agriculture.

The year 2007 brought multiple benefits, the Romanian farmers benefiting from rights like the other European farmers, the important role was played by the allocation of funds destined for agriculture and the rural development sector. Special attention was paid to the financial allocations through the National Rural Development Program (NRDP) for the period 2007-2013, which had a particularly important role for the modernization of the Romanian rural area. The program has had a positive impact on increasing added value and productivity in rural areas $[16,17]$.

Axis 1 has directly contributed to increasing value added and productivity in the agricultural sector and the food industry and indirectly to the growth of the national economy. This axis addressed the need to increase productivity levels in the agricultural sector by pursuing the objective of improving the competitiveness of rural areas, by increasing the knowledge and skills of farmers (M111), modernizing agricultural holdings (M121), increasing forested areas and promoting sustainable forest management. (M122), increasing the competitiveness of the food industry by introducing innovation and adapting businesses to EU standards (M123). Also, through M112, the renewal of the generation of future heads of agricultural holdings was promoted. 
Increasing competitiveness has focused on the efficient use of agricultural land based on a new property structure (M125), including new infrastructure, labor and well-organized farms (M141) and promoting the establishment of producer groups (M142). Despite the lower efficiency (compared to the planned targets), PNDR 2007-2013 contributed to the increase of productivity at the level of economic activities in rural areas. In particular, measures 121 and 123 had a significant impact on the increase in gross value added in the primary sector.

Table 2. Budget allocation and financial execution rate at the level of Axis 1 measures

\begin{tabular}{|c|c|c|c|c|}
\hline \multirow{2}{*}{ Measure } & \multirow{2}{*}{$\begin{array}{l}\text { Total cost } \\
\text { (mii Euro) }\end{array}$} & \multicolumn{2}{|c|}{$\begin{array}{l}\text { Value of payments made } \\
\text { (mii Euro) }\end{array}$} & \multirow{2}{*}{$\begin{array}{l}\text { Financial } \\
\text { execution } \\
\text { rate } \\
(\%)\end{array}$} \\
\hline & & Total & $\begin{array}{l}\text { from which: } \\
\text { FEADR }\end{array}$ & \\
\hline $\begin{array}{l}111-\text { Vocational training, } \\
\text { information and dissemination of } \\
\text { knowledge }\end{array}$ & $79.325,64$ & $19.347,35$ & $18.379,88$ & 24,39 \\
\hline $\begin{array}{c}112 \text { - Installation of young } \\
\text { farmers }\end{array}$ & $303.913,97$ & $298.661,38$ & $260.504,74$ & 98,27 \\
\hline $\begin{array}{l}121 \text { - Modernization of } \\
\text { agricultural holdings }\end{array}$ & $1.531 .325,19$ & $716.825,07$ & $614.443,68$ & 87,74 \\
\hline $\begin{array}{l}122 \text { - Improving the economic } \\
\text { value of the forest }\end{array}$ & $4.166,12$ & $1.877,97$ & $1.734,51$ & 81,96 \\
\hline $\begin{array}{c}123 \text { - Increasing the added value } \\
\text { of agricultural and forestry } \\
\text { products }\end{array}$ & $1.786 .571,13$ & $552.785,58$ & $478.522,28$ & 76,78 \\
\hline $\begin{array}{l}125 \text { - Improving and developing } \\
\text { infrastructure related to the } \\
\text { development and adaptation of } \\
\text { agriculture and forestry }\end{array}$ & $685.926,01$ & $525.285,41$ & $482.737,84$ & 92,42 \\
\hline $\begin{array}{l}141 \text { - Supporting semi- } \\
\text { subsistence farms }\end{array}$ & $359.568,42$ & $333.413,88$ & $297.821,89$ & 92,73 \\
\hline $\begin{array}{c}142 \text { - Establishment of producer } \\
\text { groups }\end{array}$ & $22.530,74$ & $5.452,90$ & $4.993,02$ & 24,20 \\
\hline $\begin{array}{l}143 \text { - Providing advisory and } \\
\text { consultancy services for farmers }\end{array}$ & $12.340,05$ & $5.084,77$ & $4.706,17$ & 41,21 \\
\hline Total Axis 1 & $4.785 .667,27$ & $2.458 .734,31$ & $2.163 .844,01$ & 85,22 \\
\hline
\end{tabular}

Source: data processing based on information taken from the Ministry of Agriculture and Rural Development

Axis 2 has directly contributed to the conservation of biodiversity, the maintenance of agricultural land with high natural value, the improvement of water quality, the fight against climate change and indirectly the improvement of living conditions in rural areas, as well as the adoption of a better model of sustainable development.

Table 3. Budget allocation and financial execution rate at the level of Axis 2 measures

\begin{tabular}{|c|c|c|c|c|}
\hline \multirow{2}{*}{ Measure } & \multirow{2}{*}{$\begin{array}{c}\text { Total cost } \\
\text { (mii Euro) }\end{array}$} & \multicolumn{2}{|c|}{$\begin{array}{c}\text { Value of payments made } \\
\text { (mii Euro) }\end{array}$} & $\begin{array}{c}\text { Financial } \\
\text { execution } \\
\text { rate } \\
\text { (\%) }\end{array}$ \\
\cline { 3 - 4 } & & Total & $\begin{array}{c}\text { from which: } \\
\text { FEADR }\end{array}$ & \\
\hline $211-\begin{array}{c}\text { Support for disadvantaged } \\
\text { mountain areas }\end{array}$ & $769.555,05$ & $770.594,16$ & $732.064,45$ & 100,14 \\
\hline $\begin{array}{c}212 \text { - Support for disadvantaged } \\
\text { areas - other than the mountain } \\
\text { area }\end{array}$ & $435.641,91$ & $431.637,21$ & $410.055,34$ & 99,08 \\
\hline
\end{tabular}




\begin{tabular}{|c|c|c|c|c|}
\hline $\begin{array}{c}214-\begin{array}{c}\text { Agri-environment } \\
\text { payments }\end{array} \\
215-\text { Animal welfare }\end{array}$ & $526.421,53$ & $457.489,55$ & $434.615,07$ & 86,91 \\
\hline $\begin{array}{c}\text { The first afforestation of } \\
\text { agricultural land }\end{array}$ & $3.680,42$ & 522,22 & 478,16 & 16,31 \\
\hline Total Axis 2 & $\mathbf{3 . 1 6 3 . 7 1 7 , 8 2}$ & $\mathbf{3 . 0 3 8 . 1 7 6 , 7 2}$ & $\mathbf{2 . 8 8 6 . 2 4 9 , 9 2}$ & $\mathbf{9 6 , 0 5}$ \\
\hline
\end{tabular}

Source: data processing based on information taken from the Ministry of Agriculture and Rural Development

Axes 3 and 4 have contributed to job creation in rural areas. In particular, Axis 3 has directly contributed to job creation and indirectly to the diversification of the rural economy, the creation of new local services and the development of environmental resources and cultural heritage.

Table 4. Budget allocation and financial execution rate at the level of Axis 3 measures

\begin{tabular}{|c|c|c|c|c|}
\hline \multirow{2}{*}{ Measure } & \multirow{2}{*}{$\begin{array}{c}\text { Total cost } \\
\text { (mii Euro) }\end{array}$} & \multicolumn{2}{|c|}{$\begin{array}{c}\text { Value of payments made } \\
\text { (mii Euro) }\end{array}$} & $\begin{array}{c}\text { Financial } \\
\text { execution } \\
\text { rate } \\
\text { (\%) }\end{array}$ \\
\cline { 3 - 4 } & & Total & $\begin{array}{c}\text { from which: } \\
\text { FEADR }\end{array}$ & \\
\hline $\begin{array}{c}312-\text { Support for the creation and } \\
\text { development of micro-enterprises }\end{array}$ & $625.563,20$ & $314.654,67$ & $265.071,88$ & 71,86 \\
\hline $313-\begin{array}{c}\text { Encouraging tourism } \\
\text { activities }\end{array}$ & $467.000,86$ & $137.768,25$ & $123.060,3$ & 45,39 \\
\hline $\begin{array}{c}322-\text { Renovation, development } \\
\text { of villages, improvement of basic } \\
\text { services for the economy and the } \\
\text { rural population and enhancement } \\
\text { of the rural heritage }\end{array}$ & $1.627 .359,37$ & $1.498 .500,02$ & $1.248 .530,46$ & 93,88 \\
\hline Total Axis 3 & $\mathbf{2 . 7 1 9 . 9 2 3 , 4 3}$ & $\mathbf{1 . 9 5 0 . 9 2 2 , 9 4}$ & $\mathbf{1 . 6 3 6 . 6 6 2 , 6 4}$ & $\mathbf{8 3 , 4 5}$ \\
\hline
\end{tabular}

Source: data processing based on information taken from the Ministry of Agriculture and Rural Development

Axis 4 has directly contributed to job creation and improved local governance and indirectly to the diversification of the rural economy and the increased involvement of private partners in local development strategies through the LEADER approach.

Table 5. Budget allocation and financial execution rate at the level of Axis 4 measures

\begin{tabular}{|c|c|c|c|c|}
\hline \multirow{2}{*}{ Measure } & \multirow{2}{*}{$\begin{array}{l}\text { Total cost } \\
\text { (mii Euro) }\end{array}$} & \multicolumn{2}{|c|}{$\begin{array}{l}\text { Value of payments made } \\
\text { (mii Euro) }\end{array}$} & \multirow{2}{*}{$\begin{array}{c}\text { Financial } \\
\text { execution } \\
\text { rate } \\
(\%)\end{array}$} \\
\hline & & Total & $\begin{array}{l}\text { from which: } \\
\text { FEADR }\end{array}$ & \\
\hline $\begin{array}{l}\text { 4.1 Implementing local } \\
\text { development strategies }\end{array}$ & $451.874,74$ & $298.576,91$ & $283.202,34$ & 94,60 \\
\hline $\begin{array}{l}\text { 4.21 Implementation of } \\
\text { cooperation projects }\end{array}$ & $3.749,70$ & $1.121,87$ & $1.065,78$ & 34,99 \\
\hline $\begin{array}{l}\text { 4.31 Functioning of Local Action } \\
\text { Groups }\end{array}$ & $68.470,19$ & $53.615,59$ & $49.379,77$ & 79,62 \\
\hline Total Axa 4 & $524.094,63$ & 353.314,37 & $333.647,89$ & 91,49 \\
\hline
\end{tabular}

Source: data processing based on information taken from the Ministry of Agriculture and Rural Development

In the case of axes 1 and 3, the level of financial absorption was lower compared to axes 2 and 4, the main cause being the difficulty of the beneficiaries to ensure the co-financing rate, both from own resources and from borrowed resources. 
While in NRDP 2007-2013 the focus has been on large-scale economies and increasing competitiveness, the need to protect land, water, natural resources, rural environment and improving the quality of life, NRDP 2014-2020 addresses weaknesses, uses opportunities based on NRDP progress 2007-2013 and addresses existing weaknesses. The measures related to PNDR 2014-2020 focus on agri-food processing, modernization of agricultural holdings, rejuvenation of farmers, development of infrastructure and various local economies.

PNDR 2024-2020 relies on the maximum impact and solving structural problems for agricultural holdings, with the help of Local Action Groups in the idea of sustainable development of rural areas. The total funds have a value of over 9 billion Euros, of which 8.1 billion Euros are allocated to the EAFRD and 1.3 billion Euros from the state budget. These funds are divided between the development of enterprises and farms, the renewal of rural villages, physical assets, the transfer of shares and knowledge and LEADER.

Table 6. The situation of the contracted and completed projects in the period 2014-2020

\begin{tabular}{|c|c|c|c|c|}
\hline \multirow{2}{*}{ Sub-measure } & \multicolumn{2}{|c|}{ Contracted projects } & \multicolumn{2}{c|}{ Completed projects } \\
\cline { 2 - 5 } & Number & Value & Number & Value \\
\hline $\begin{array}{c}\text { Sub-measure 1.1 "Support for } \\
\text { vocational training and skills } \\
\text { acquisition" }\end{array}$ & 98 & $6,625,855$ & 20 & $1,459,228$ \\
\hline $\begin{array}{c}\text { Sub-measure 4.1 "Investments in } \\
\text { agricultural holdings" }\end{array}$ & 1,288 & $372,124,073$ & 21 & $16,796,105$ \\
\hline $\begin{array}{c}\text { Sub-measure 4.1 "Investments in } \\
\text { fruit farms" }\end{array}$ & 92 & $38,141,313$ & 11 & $4,975,733$ \\
\hline $\begin{array}{c}\text { Sub-measure 4.2 "Support for } \\
\text { investments in the processing / } \\
\text { marketing of agricultural products" }\end{array}$ & 84 & $49,688,950$ & 16 & $18,302,316$ \\
\hline $\begin{array}{c}\text { Sub-measure 4.2a "Investments in the } \\
\text { processing / marketing of fruit } \\
\text { products" }\end{array}$ & 4 & $2,809,226$ & 4 & 661,901 \\
\hline $\begin{array}{c}\text { Sub-measure 6.1 "Support for the } \\
\text { installation of young farmers" }\end{array}$ & 9,532 & $391,410,000$ & 15 & 610,000 \\
\hline $\begin{array}{c}\text { Sub-measure 6.2 "Support for the } \\
\text { establishment of non-agricultural } \\
\text { activities in rural areas" }\end{array}$ & 629 & $35,870,000$ & 16 & 940,000 \\
\hline $\begin{array}{c}\text { Sub-measure 6.3 "Support for the } \\
\text { development of small farms" }\end{array}$ & 7,076 & $106,140,000$ & 28 & 420,000 \\
\hline $\begin{array}{c}\text { Sub-measure 6.4 "Investments in the } \\
\text { creation and development of non- } \\
\text { agricultural activities" }\end{array}$ & 431 & $62,958,700$ & 57 & $9,160,794$ \\
\hline $\begin{array}{c}\text { Sub-measure 7.2 "Investments in the } \\
\text { creation and modernization of small- } \\
\text { scale basic infrastructure - road } \\
\text { infrastructure of local interest" }\end{array}$ & 118 & $118,038,782$ & 1 & $1,000,000$ \\
\hline
\end{tabular}

Source: $\quad$ https://www.madr.ro/pndr-2014-2020/implementare-pndr-2014-2020/situatia-proiectelordepuse-2014-2020.html, accessed on 15.11.2020

Table 6 presented the situation of projects contracted and completed on the main submeasures of the NRDP 2014-2020 aimed at increasing competitiveness; natural resource management in the face of climate change; a balanced development of the rural environment and respectively the reduction of the gaps between the areas of the country.

For the financial year 2014-2020, there were a number of impediments to the implementation of the proposed objectives of the NRDP: increased fragmentation of agricultural land with many small farms that are not eligible for European funds, In addition 
to an aging population rural area, but with a high percentage of the active population involved in agriculture and last but not least a cumbersome administration of these funds due to bureaucracy.

\section{Conclusions}

In the period 2007-2014, the strategic guidelines took into account the potential of the food, agricultural and forestry sectors to produce goods of high quality and value, in order to meet the varied and ever-changing needs of the people. The first and most important challenge was the modernization and development of the forestry, agricultural and food sectors, so as to achieve a degree of competitive profitability. This is the reason why Axis 1 was considered the most important priority of Romania's NRDP.

Regarding Axis 2, the strategic guidelines highlighted the achievement of environmental objectives. European priorities such as water, climate change and biodiversity were addressed.

For Axis 3 and Axis 4, the strategic guidelines set out certain priority issues, such as the conditions for growth, job creation, maximum exploitation of rural areas and local governance. These two axes represented the second place measures, in order of financial importance. The possibility of the agricultural exodus and the high level of work led to a restructuring of the agricultural sector, and implicitly, to the need for the non-agricultural rural economy to be more and more developed, and Axis 3 and Axis 4 provided support in this regard.

The available data show important differences between the NRDP measures: some of them are in a good situation, but some of them are delayed. At the same time, there are differences between the coordinates of the NRDP and those of rural areas and hence the importance of LAGs for the implementation of local development strategies based on the needs identified in a timely manner at the area level.

In the current programming period and in the future, Romania must act in the direction of increasing the capacity of rural areas to absorb community funds, in order to create and consolidate farms of European size. The results show that there is no perfect match between the financial support scheduled in both programming periods and the Romanian rural reality. In order to maximize the impact of the support, it is necessary to reconsider some aspects of the financial schemes for the next intervention period: 2021-2027.

\section{References}

Journals:

1. Alexandri C., Giurca D., Luca (2020) L'agriculture en Roumanie, entre transformation et coexistence des modèles, IRIS Editions, p. 161-176

2. Anghelache C., Avram D., Burea D., Mirea M. (2019) Accesarea fondurilor europene prioritate pentru România. Romanian Statistical Review - Supplement nr. 1 / 2019, p. $110-123$

3. Borza M. (2016) Agricultura românească în tranziție: schimbări, provocări și particularităţi. Revista Economie, Finanţe, Politici Sociale, Demografie, Statistică şi Econometrie, Ediţia a VII-a, nr. 1, p 8-15

4. Dobre R., Cîrstea A. C. (2013) - Land property structure - a limiting factor in strengthening the agricultural holdings. Scientific Papers Series Management, Economic Engineering in Agriculture and Rural Development, Vol. 13, Issue 2 
5. Filip A., MAteoc-Sîrb N., Csosz I. (2019) European funds for rural developmentparticularities and comparisons. Lucrări Științifice Seria I, Management Agricol, Vol. 21 Issue 3, p. 313-320

6. Lupu G. (2020) Evolution of the Common Agricultural Policy in Romania between 2014-2020. Scientific Papers Series Management, Economic Engineering in Agriculture and Rural Development, Vol. 20, Issue 2

7. Mihaleache F. (2013) O analiză critică asupra dezvoltării agriculturii şi zonelor rurale, pe baza PNDR 2007-2013. Revista Calitatea vieții, Issue No: 3, p. 277-294

8. Otiman P.I. (2012) Structura agrară actuală a României - o mare şi nerezolvată problemă socială şi economică a țării. Revista Română de Sociologie, serie nouă, anul XXIII, nr. 5-6, p. 339-360

9. Porumbăcean C. (2010) Politica agricolă comună a UE si aplicarea acesteia în România. Revista Societate și politică, Issue No: 2, p. 96-111

10. Raicov M., Mănescu C., Mateoc-Sîrb N. (2012) Studiu privind dezvoltarea rurală în Politica Agricolă Comună a Uniunii Europene. Buletinul AGIR nr. 3, p. 59-61

11. Vulpe A. G. (2019) Oportunități generate de economia colaborativă în creșterea performanțelor sectorului agricol. Revista de Filosofie, Sociologie și Științe Politice , nr. 1 (179), p.227-234

12. Turek_Rahoveanu Adrian (2007). Evoluţia formelor de proprietate funciară în agricultura României. Editura Cartea Universitară

13. Turek_Rahoveanu Adrian (2019). Rural Areas - ways of using rural areas for a sustainable development. Lambert Academic Publishing

14. Zahiu Letiția, Toma Elena, Dachin Anca, Alexandri Cecilia, (2010) - Agricultura în economia României : intre așteptări si realități, Editura Ceres

15. Buzoianu O., Pascu B., Popescu M. (2017) Analiza sectorului agricol în cadrul Uniunii Europene. Culegere de articole selective ale Conferinţei Ştiinţifice Internaţionale „Competitivitatea şi Inovarea în Economia Cunoaşterii”, Chişinîu, Rep. Moldova

16. Florescu M. F., Podaru A. M., Turek-Rahoveanu A. (2018). The impact of the agricultural holding restructuring measures in the programming period 2007-2013. Proceedings of the The 31 st International Business Information Management (IBIMA) Conference Milan, Italy

17. Turek-Rahoveanu A. (2018). Impact of the implementation of the NRDP 2007-2013 measures on the romanian rural area: Proceedings of the The 31st International Business Information Management (IBIMA) Conference, Milan, Italy 